IZA DP No. 9778

The Labor Supply of Fixed-Wage Workers:

Estimates from a Real Effort Experiment

Jeffrey Carpenter

February 2016

Forschungsinstitut

zur Zukunft der Arbeit

Institute for the Study

of Labor 


\title{
The Labor Supply of Fixed-Wage Workers: Estimates from a Real Effort Experiment
}

\author{
Jeffrey Carpenter \\ Middlebury College \\ and IZA
}

\section{Discussion Paper No. 9778 \\ February 2016}

\author{
IZA \\ P.O. Box 7240 \\ 53072 Bonn \\ Germany \\ Phone: +49-228-3894-0 \\ Fax: +49-228-3894-180 \\ E-mail: iza@iza.org
}

Any opinions expressed here are those of the author(s) and not those of IZA. Research published in this series may include views on policy, but the institute itself takes no institutional policy positions. The IZA research network is committed to the IZA Guiding Principles of Research Integrity.

The Institute for the Study of Labor (IZA) in Bonn is a local and virtual international research center and a place of communication between science, politics and business. IZA is an independent nonprofit organization supported by Deutsche Post Foundation. The center is associated with the University of Bonn and offers a stimulating research environment through its international network, workshops and conferences, data service, project support, research visits and doctoral program. IZA engages in (i) original and internationally competitive research in all fields of labor economics, (ii) development of policy concepts, and (iii) dissemination of research results and concepts to the interested public.

IZA Discussion Papers often represent preliminary work and are circulated to encourage discussion. Citation of such a paper should account for its provisional character. A revised version may be available directly from the author. 
IZA Discussion Paper No. 9778

February 2016

\section{ABSTRACT}

\section{The Labor Supply of Fixed-Wage Workers: Estimates from a Real Effort Experiment}

Fixed-wage workers comprise the bulk of the labor force and yet little is known about how they respond to wage changes. Given recent interest in theories of reciprocity and intrinsic motivation and their implications for effort provision, the neoclassical prediction seems less obvious today. To better understand the motivation of these workers, I estimate their labor supply using a real effort experiment. Two results stand out. First, no one theory seems to fit the pooled data. On average, people work considerably harder than the minimum but they do not respond to changes in the wage. Second, pooling the data is deceptive because there seem to be distinct types with differing responses to the wage. Most workers can be classified as reciprocal or intrinsically motivated and, indeed, these types respond as theory would predict: reciprocators return wage gifts with increased effort and extrinsic incentives crowd out motivation for intrinsic workers.

JEL Classification: C91, J22

Keywords: labor supply, fixed wage, reciprocity, intrinsic motivation, real effort, experiment

Corresponding author:

Jeffrey Carpenter

Department of Economics

Middlebury College

Middlebury, VT 05753

USA

E-mail: jpc@middlebury.edu 


\section{Introduction}

The study of labor supply is foundational within economics - the relationship between the wages offered by firms and the effort provided by workers forms the basis for public policy debates that inform the evaluation of tax and welfare programs and the design of labor market interventions. Concomitant with the importance of this relationship, the literature offering estimates of labor supply is vast and considers many important differences such as those in worker characteristics (e.g., union status, gender), in sectors (e.g., private versus public) and in compensation schemes (e.g., performance pay and group incentives) to mention just a few (Ashenfelter and Layard, 1986; Ashenfelter and Card, 1999). I focus on two aspects of the labor contract that determine the working conditions for a large, but understudied, portion of the labor force, namely the labor supply of unmonitored fixed-wage workers. Indeed, surveys suggest that despite an increase in the use of performance pay for managers and executives, most non-exempt salaried or hourly employees, perhaps the bulk of the labor force, continue to work without performance incentives (Ledford, 2014). These employees are paid a simple fixed wage (per annum or per hour) with no bonus, piece rate or profitsharing and although they may not have much choice over how long they must be at work, they do have considerable latitude in determining how hard to work (Hamermesh and Wolfe, 1990).

In this setting the boss cannot contract for an effort level and therefore the predictions of static principal-agent theory seem straightforward: because workers receive the fixed wage regardless of their performance, if effort is costly they should not work very hard, i.e., they should "shirk" (Akerlof, 1982; Bowles, 1985). As a result, the neoclassical theory predicts that effort will fall to some minimum and should be invariant to changes in the fixed wage. However, only the prediction that effort should not respond to changes in the fixed wage is crisp. If workers eschew extrinsic rewards and yet are intrinsically motivated to provide some "whistle while you work" level of effort (a la Deci and Ryan 1985), they may work considerably more than the minimum. That said there is no reason to believe that intrinsically motivated workers will increase their efforts when the fixed payment is raised (Benabou and Tirole, 2003).

Based on the reciprocal nature of workers, Akerlof (1982) proposes an alternative prediction for this setting, one in which workers repay higher than equilibrium wage "gifts" by working more than the minimum. In particular, the posited effort norm governing worker reciprocity is increasing in the firms' wage (relative, perhaps, to some "fair" reference wage) and so the larger the wage rent, the harder the employee should work This logic suggests a labor supply curve that will be upward sloping in the standard absence of income effects. 
Labor supply estimates of fixed-wage workers based on observational data tend to exploit changes in the tax code (Keane, 2011) or other legislative interventions that affect salaries (e.g., Fisman et al., 2012). The typical finding is that the elasticity of labor supply is relatively low despite upward bias resulting from confounding effects on the extensive margin (Heckman, 1993). In addition to the problems of identifying the effect of wage changes on the intensive margin, observational studies suffer from other selection issues and the bias associated with plausibly important unobservables. With this in mind, a number of careful case studies and field experiments have been conducted recently. For example, Oettinger (1999) estimates the labor supply of stadium vendors, Camerer et al. (1997), Crawford and Ming (2011) and Farber (2014) all examine taxi drivers, Fehr and Goette (2007) study bicycle messengers and Bellemare and Shearer (2011) study labor supply effects among tree planters. Though tempting to do so, it is hard to make comparisons between these innovative studies and the experiment described below because workers in these studies are all offered performance incentives, not fixed wages. Likewise, in the experimental lab, labor supply estimates based on real effort tend to rely on piece rate employment contracts (e.g., Swenson, 1988; Dickinson, 1999; Sillamaa, 1999, Huet-Vaughn, 2015) and are therefore also not directly comparable.

Considering real effort experiments that are more similar because they use fixed-wage contracts, Gneezy and List (2006) and Kube et al. (2012) conduct gift exchange experiments with people hired for short term jobs. Among library workers and donation solicitors, Gneezy and List (2006) confirm gift exchange in the short term. Within 90 minutes of the start of a day's work, output is greater for those paid a high fixed wage compared to those paid a low wage but the effect fades. Also utilizing temporary library workers, Kube et al. (2012) show that worker reciprocity is stronger when the gifts take a non-monetary form. While illustrative of worker motivation, these studies were not designed to estimate labor supply and it is hard to make any inferences based on just two wage treatments.

To more directly study the labor supply of unmonitored fixed-wage workers, I conduct a similar experiment to those just mentioned in that workers are hired for a one-time job to do clerical work. The benefit of one-time employment is that our estimates will not be confounded by repeated game or reputational effects. What is different, however, is that workers in this study are randomly assigned to one of five wage treatments, including wages at and on either side of a standard (reference) wage for this type of work. In addition, workers fill out a survey including a standard personality scale and a few other attitudinal questions.

Overall, I find that the employees do a considerable amount of work in contrast to the neoclassical prediction but that labor supply is, on average, inelastic and slightly downward 
sloping, though not significantly so. What makes the point estimates negative is a unique aspect of the design, namely that workers are unpaid volunteers in one of the treatments and it appears that financial compensation crowds out intrinsic motivation, to some extent. While this fact is consistent with the literature on intrinsic motivation, the fall off from the volunteer condition is not dramatic in the pooled data. At the same time, because labor supply is essentially flat, at first blush we find little evidence of gift exchange.

However, digging a bit deeper, it appears that the response to the wage treatments is heterogeneous. While standard personality attributes appear to matter little, a question designed to measure the extent to which workers subscribe to reciprocity norms essentially bifurcates our sample. Those who subscribe to the norm of "returning favors" behave very differently from those who do not. Indeed, there appear to be two clear types of workers: reciprocators whose labor supply is upward sloping through the reference wage and those who appear intrinsically motivated (confirmed by a standard question from an intrinsic motivation inventory). This second group of employees works considerably harder as volunteers than when they are paid.

In what follows I explain the details of the experiment, present a full set of the results and, in a final section, discuss these findings in relation to a few additional studies that uncover similar labor supply phenomena.

\section{Study design}

One hundred and seventy-five participants were recruited into fifteen sessions from the student population at Middlebury College to fill out a survey for which they earned five dollars. Ostensibly, the purpose of the sessions was to gather opinions and expectations of the students about their choices of major and their career aspirations and expectations. Along with questions on this topic, participants also completed the 44-item Big Five personality inventory (John et al., 2008) and a standard set of demographics. The survey was conducted at a central location (the main library at the center of campus) and was expected to take half an hour though participants were told to plan on the sessions taking up to an hour. The participants were explicitly told that the five-dollar payment was just for filling out the survey and that the payment was set to match the going rate on campus for student workers of ten dollars per hour. All this was done to prime a common reference wage for all participants and to prevent any selection into the wage treatments.

Once the survey had been completed the participants, who had been randomly placed in cubicles and told not to communicate with each other (to minimize peer effects), were asked to stay for another half an hour to do some related clerical work for the College. Specifically, 
they were asked to fold, seal and hand-address newsletters to be sent to alumni. It was at this point that participants were randomly assigned to a wage treatment. So that there would be no invidious comparisons made between participants during the experiment, the wage was assigned at the level of the session. There were five wage treatments (three sessions per treatment) in which participants were paid fixed wages of $\$ 0, \$ 1, \$ 5, \$ 10$ or $\$ 20$ for their clerical work. The participants were explicitly told that they would earn the assigned wage regardless of how much output they produced. As a unique aspect of our design, in the $\$ 0$ condition the participants worked as volunteers without pay. ${ }^{1}$

Before work began, the participants were provided with blank newsletters, circular stickers to seal the folded newsletters, pens and address lists of alumni to whom the mailers were to be sent. An experimenter demonstrated the production process and then instructed the participants to produce one mailer at a time. After the half hour was over, participants were asked to fill out another very brief questionnaire and to tidy up their workstations while they waited to be paid. Payments were made, one at a time.

\begin{tabular}{lccccc}
\hline \multicolumn{5}{c}{ Table 1: Worker Characteristics (by wage treatment) } \\
\hline \multirow{2}{*}{ Age } & $\$ 0$ & $\$ 1$ & $\$ 5$ & $\$ 10$ & $\$ 20$ \\
\cline { 2 - 6 } Male (I) & 19.71 & 19.61 & 19.57 & 19.68 & 19.56 \\
Caucasian (I) & 0.60 & 0.67 & 0.70 & 0.53 & 0.53 \\
High GPA (I) & 0.66 & 0.67 & 0.67 & 0.68 & 0.53 \\
Economic Major (I) & 0.23 & 0.33 & 0.38 & 0.32 & 0.31 \\
Extroversion (FS) & -0.03 & -0.18 & 0.19 & 0.16 & 0.28 \\
Agreeableness (FS) & 0.03 & -0.05 & -0.0 .12 & 0.04 & 0.10 \\
Conscientiousness (FS) & -0.20 & 0.02 & 0.07 & 0.20 & -0.12 \\
Neuroticism (FS) & -0.18 & 0.08 & 0.31 & -0.15 & -0.07 \\
Openness (FS) & 0.03 & -0.22 & 0.11 & -0.14 & 0.24 \\
\hline
\end{tabular}

Notes: Characteristic means reported; (I) and (FS) stand for indicator and factor score, respectively; Only three differences are significant at the 5\% level (neuroticism between $\$ 5$ and $\$ 0, \$ 5$ and $\$ 10$ and openness between $\$ 1$ and $\$ 20)$.

Table 1 lists the mean characteristics of our participants by wage treatment. Overall, participants were between 19 and 20 years old, on average, $60 \%$ of them were male, $64 \%$ were Caucasian, $31 \%$ had a high (self-reported) grade point average (greater than a 3.8 on

\footnotetext{
${ }^{1}$ The instructions for the experiment, which were approved by the Middlebury College IRB, appear in the appendix.
} 
a standard 4 point scale) and 20\% were economics majors (a number that matches the College population). In terms of personality traits, our results from the Big Five are typical: all five main components (extroversion, agreeableness, conscientiousness, neuroticism, and openness) generated substantial eigenvalues when factor analysis was conducted. Considering randomization to treatment, only three differences out of one hundred are significant at the $5 \%$ level indicating the treatments were well-balanced.

\section{$3 \quad$ Labor supply estimates}

We use participant output as our measure of effort. Starting broadly, our participants, pooled across treatments, produced an average of 22.70 units of output and efforts were heterogeneous (s.d. 8.11). While five participants produced 40 units or more, seven decided to produce nothing.

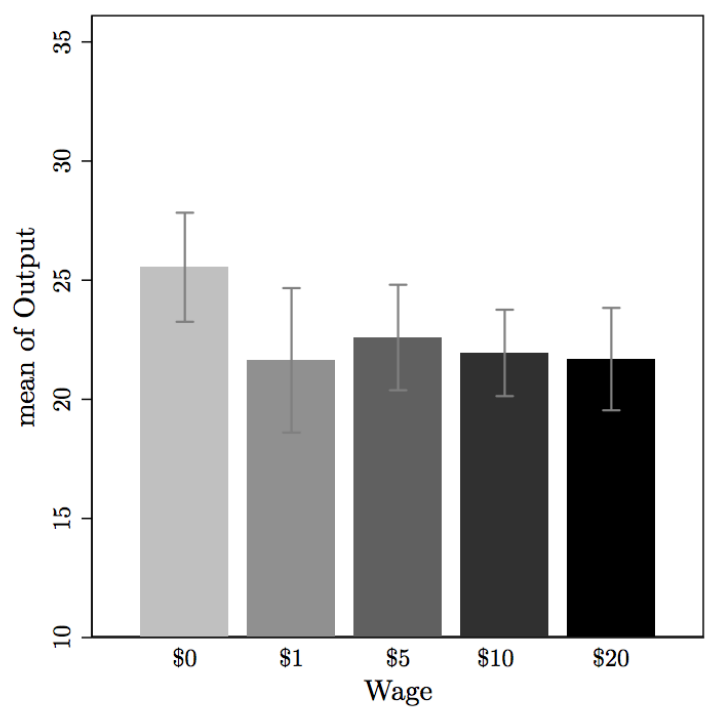

Figure 1: Output by Wage Treatment.

Figure 1 presents mean output levels in the different wage treatments. The first thing to notice is that, on average, participants worked hardest when they were paid nothing. However, while the differences between the mean output at $\$ 0$ and the means at $\$ 10$ and $\$ 20$ are significantly different at the $5 \%$ level, none of the other differences are significant and, as a result, the implied labor supply curve is essentially flat.

The shape of the labor supply curve is confirmed in Table 2 in which the wage is treated as a continuous variable. In columns (1) and (3) the bi-variate relationship is estimated and we see that each dollar increase in the wage is associated with a one-tenth a unit decrease 
in output. In columns (2) and (4) we include controls for age, sex, race, GPA, major and personality and the point estimate increases in magnitude, but just a bit. For the interested reader, a full table of point estimates is included in the appendix where one can assess the impact of the controls. ${ }^{2}$ To account for any differences in the sessions, in columns (1) and (2) the standard errors are clustered at the session level and in columns (3) and (4) we include session level random effects, instead. These changes matter little to the point estimates or their significance. As indicated by the results in Table 2, the labor supply curve generated in the experiment is flat and effort does not seem to be determined by the wage paid.

\begin{tabular}{lllll}
\hline \multicolumn{5}{c}{ Table 2: Labor Supply } \\
\hline \multirow{2}{*}{ Wage } & $(1)$ & $(2)$ & $(3)$ & $(4)$ \\
& -0.112 & -0.143 & -0.104 & $-0.143^{*}$ \\
& $(0.107)$ & $(0.105)$ & $(0.139)$ & $(0.086)$ \\
\hline Controls included & No & Yes & No & Yes \\
Errors clustered on session & Yes & Yes & No & No \\
Session random effects & No & No & Yes & Yes \\
Observations & 175 & 175 & 175 & 175 \\
\hline
\end{tabular}

Notes: Dependent variable is individual output; marginal effects and robust standard errors reported; ${ }^{*} \mathrm{p}<0.10$; controls include age, sex, race, GPA, major, big 5 personality.

Considering the theoretical predictions outlined in the introduction, the neoclassical model does not seem to fit well. As pointed out above, less than five percent of workers produce nothing and the median worker produces almost one unit of output per minute. In other words, our participants work too hard to be consistent with the neoclassical model. At the same time, we also do not find any evidence of gift exchange in the pooled data, which would have predicted an upward sloping labor supply curve through the reference $\$ 5$ wage. As is clear from the discussion above, if anything, the labor supply curve is actually downward sloping. The last theory, that of intrinsic motivation, seems to fit the pooled data best, thought it is also not a perfect match. On the one hand, people do work more than the minimum and so they seem intrinsically motivated to work for the College and there does appear to be some crowding of this motivation by extrinsic incentives because average output is lower when workers are paid a positive amount. On the other hand, the drop off in motivation due to extrinsic incentives is rather weak and not robustly significant.

So where does this leave us? While none of the standard theories are a paricularly good match with the labor supply estimates from the experiment considered overall, in the next

\footnotetext{
${ }^{2}$ For example, we find that men produce significantly less than women and personality has little impact on effort.
} 
section, we see that heterogenous treatment effects of the wage appear when one explicitly accounts for differences in motivation. In other words, our pooled results are misleading because they represent a mixture of different worker types.

\section{Heterogeneous treatment effects}

To more directly examine the implications of reciprocity and intrinsic motivation, we incorporated two standard survey-based measures in our design. First, as part of the initial questionnaire participants were asked to respond to a statement about their adherence to reciprocal norms. Responses to the statement, "If someone does me a favor, I am eager to return it", were measured on a likert scale. The statement was borrowed from the German Socio-Economic Panel and has been discussed as a valid measure of reciprocity in Dohmen et al., (2008). Second, as is standard in the psychology literature on motivation, we elicited responses to another statement at the end of production, "I enjoyed doing this activity very much". This item was taken from the Intrinsic Motivation Inventory developed in Ryan (1982) and McAuley et al. (1989). Based on the responses to these statements, we created two indicator variables by separating the data at the median of each set of responses. We call reciprocal workers those for whom the first statement was representative and intrinsic workers those for whom the second resonated.
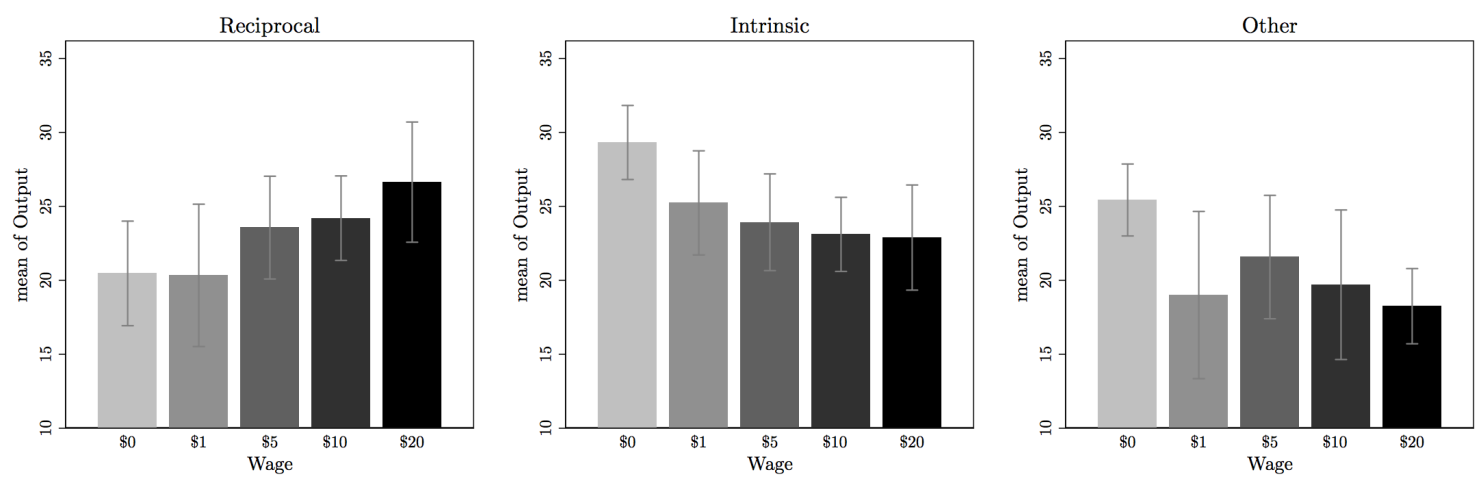

Figure 2: Heterogeneous Treatment Effects of the Wage.

In Figure 2 we illustrate how the different types of workers reacted to changes in the fixed wage. Starting on the left with the reciprocal workers, we see an interesting divergence from the pattern in Figure 1 - those workers who identify most strongly with reciprocity norms do appear to reciprocate gifts. The labor supply for this subsample is, indeed, upward sloping as gift exchange would predict. In the middle panel we see the behavior of intrinsic workers who demonstrate a more pronounced version of Figure 1, one in which the drop-offs 
of effort from the volunteer condition are more pronounced. Lastly, on the right we report the mean behavior of those workers who were classified neither as reciprocal nor intrinsic. While somewhat lower than the other two types (and so closer to the neoclassical prediction), the mean efforts of these workers, who comprise only a third of the sample, are more variable and do not form as clear a pattern.

\begin{tabular}{|c|c|c|c|c|}
\hline & $(1)$ & $(2)$ & $(3)$ & $(4)$ \\
\hline \multirow[t]{2}{*}{ Wage } & -0.202 & -0.216 & -0.182 & $-0.216^{*}$ \\
\hline & $(0.117)$ & $(0.133)$ & $(0.173)$ & $(0.120)$ \\
\hline \multirow[t]{2}{*}{ Reciprocal Worker (I) } & $-4.001^{* *}$ & $-3.583^{* *}$ & $-3.846^{* * *}$ & $-3.583^{* *}$ \\
\hline & $(1.499)$ & $(1.560)$ & $(1.489)$ & $(1.649)$ \\
\hline \multirow[t]{2}{*}{ Wage $\times$ Reciprocal Worker } & $0.662^{* * *}$ & $0.601^{* * *}$ & $0.664^{* * *}$ & $0.601^{* * *}$ \\
\hline & $(0.120)$ & $(0.129)$ & $(0.159)$ & $(0.166)$ \\
\hline \multirow[t]{2}{*}{ Intrinsic Worker (I) } & $6.297^{* * *}$ & $5.720^{* *}$ & $6.437^{* * *}$ & $5.720^{* * *}$ \\
\hline & $(1.993)$ & $(2.365)$ & $(1.554)$ & $(1.687)$ \\
\hline \multirow[t]{2}{*}{ Wage $\times$ Intrinsic Worker } & $-0.359^{* * *}$ & $-0.339^{*}$ & $-0.375^{* *}$ & $-0.339 * *$ \\
\hline & $(0.142)$ & $(0.189)$ & $(0.164)$ & $(0.173)$ \\
\hline \multirow[t]{2}{*}{ Wage $+($ Wage $\times$ Recip $)$} & $0.460^{* * *}$ & $0.385^{* *}$ & $0.482^{* *}$ & $0.385^{* * *}$ \\
\hline & $(0.124)$ & $(0.1838)$ & $(0.188)$ & $(0.146)$ \\
\hline \multirow[t]{2}{*}{ Wage + (Wage $\times$ Intri $)$} & $-0.561^{* * *}$ & $-0.555^{* *}$ & $-0.557^{* * *}$ & $-0.555^{* * *}$ \\
\hline & $(0.167)$ & $(0.189)$ & $(0.128)$ & $(0.152)$ \\
\hline Controls included & No & Yes & No & Yes \\
\hline Errors clustered on session & Yes & Yes & No & No \\
\hline Session random effects & No & No & Yes & Yes \\
\hline Observations & 175 & 175 & 175 & 175 \\
\hline
\end{tabular}

Notes: Dependent variable is individual output; marginal effects and robust standard errors reported; ${ }^{*} \mathrm{p}<0.10,{ }^{* *} \mathrm{p}<0.05,{ }^{* * *} \mathrm{p}<0.01$; controls include age, sex, race, GPA, major, big 5 personality.

To test more explicitly for heterogeneous labor supply effects, in Table 3 we report point estimates from regressions in which the type indicators and their interactions with the wage treatments have been added. The table is similar in structure to Table 2 in that the first two columns of the table include clustered standard errors, the second two employ random effects 
instead and controls are added in columns (2) and (4). Given we have included the types and allowed their labor supplies to differ, the point estimate on "Wage" is the slope of labor supply for the "other" workers. As in Table 2, these workers do not respond significantly to the wage.

The place to focus attention in Table 3, however, is near the bottom where the estimates of the slopes of the type-specific labor supply curves are calculated. The effect of the wage for reciprocal workers is the sum of the Wage point estimate just discussed and the relevant interaction. This estimate hovers around 0.4 and is significantly positive in all four columns. It appears that labor supply does slope upwards through the reference wage, though only for reciprocal workers. By contrast, for the intrinsic workers the estimate of the slope of labor supply is significantly negative. Intrinsically motivated workers do appear to eschew monetary compensation for this task - the slope of their labor supply is -0.55 with most of the effect being driven by the considerable efforts given by these workers when asked to volunteer. ${ }^{3}$

\section{Discussion}

Fixed-wage workers comprise the bulk of the labor force and yet little is known about how these employees respond to changes in their wages. Undoubtedly, part of the reason these workers have been somewhat ignored is that the answer seemed obvious from the neoclassical point of view: without incentives these employees should not work hard, nor should they respond positively to increases in the fixed wage. However, given recent interest in reciprocity and intrinsic motivation and their implications for motivation, this prediction seems less obvious today and so to better understand the motivation and psychology of these workers, I estimate their labor supply using a real effort experiment. The data from this experiment suggest two "take home" messages. First, no one theory seems to fit the pooled data. On average, people work considerably harder than the minimum (so the neoclassical model does not work well) but they do not respond to changes in the wage from a starting point of zero (so neither reciprocity nor intrinsic motivation fit well either). Second, pooling the data is deceptive because there seem to be distinct types with heterogeneous responses to the wage. Significant portions of our sample can be classified as reciprocal or intrinsically motivated and, indeed, these "types" respond as theory would predict: reciprocators return wage gifts with increased effort and extrinsic incentives crowd out motivation for intrinsic workers.

As I mentioned at the start, there are surprisingly few papers that estimate labor supply

\footnotetext{
${ }^{3}$ As with Table 2, the full set of point estimates for Table 3, including those for the controls, appears in the appendix.
} 
for this type of worker - as far as I know this is the only real effort experiment designed explicitly to do so (others use chosen effort, incentive pay, or have only two wage conditions which is not enough to estimate a full supply curve). However, there are two papers, designed for other purposes, that dovetail with the current results nicely. Concerning the behavior of workers who may be intrinsically motivated, Gneezy and Rustichini (2000) examine the efforts of 180 high school workers hired to collect charitable donations. These workers are randomized into three wage conditions: unpaid (volunteers), those who earn $1 \%$ of the total amount that they raise and those who earn 10\%. Like the current experiment, Gneezy and Rustichini's volunteers appeared to work the hardest. Unlike their participants, however, even very high fixed wages were not enough to motivate workers on average in this experiment. Considering reciprocal workers instead, Cohn et al., (2014) study 196 workers hired to do a short-term job (hand out promotional copies of a newspaper). Here the question is whether workers will reciprocate a wage gift. In their within-subjects design, workers are exposed to two wages, asked about how fair they thought the wages were and then, later, asked to participate in a reciprocity experiment. Like the current data, there is not a lot of evidence of reciprocity in the pooled data of Cohn et al. However, when the authors test for heterogeneous treatment effects using their wage fairness perceptions and the typology resulting from the experiment, they find something very similar to the current experiment. Workers categorized as reciprocal by the experiment did respond significantly positively to the wage gift and the effect did not fade. ${ }^{4}$ Again however, neither of these studies was designed to estimate the labor supply of fixed-wage workers (Gneezy and Rustichini use performance incentives and have just three wage treatments while Cohn et al. have only two wage treatments) and so the current estimates are somewhat unique.

What are the implications of the labor supply curves that I have estimated? In the pooled sample there seems to be good news and bad news. The good news is that neoclassical theory does not fit well because people do not just give a minimum of effort. Most workers gave considerably more. The bad news is that the workers, taken as a whole, do not respond to increases in the fixed wage. Does this mean that wage gifts are just a waste of money from an organization's point of view? Not necessarily. The representative worker masks considerable heterogeneity and whatever determines the mixture within an organization must certainly play an important role. If the organization were one in which norms of reciprocity are primed, low fixed wages would be a disaster, for example. As the discussion in Heyman and Ariely (2004) of social and monetary markets suggests, context is likely to be very important in the workplace. Workers may fall back on norms of reciprocity when triggered by a traditional (perhaps exploitative) workplace environment and in this case wage gifts

\footnotetext{
${ }^{4} \mathrm{~A}$ similar result, though in the context of training, has recently been demonstrated in Sauermann (2015).
} 
will matter considerably. But workers may instead rely on intrinsic motivation when the context is more social or, as is demonstrated in Carpenter and Gong (2015), the mission of the firm matches one's values more closely. Here, conditional on rising to some common reference wage, everyone concerned may be happier if resources were used for things other than wages. The point, perhaps, is that setting a fixed wage that is optimal for all in an organization may be impossible given the heterogeneity we find, but perhaps one can at least do pretty well by matching the wage policy to firm "culture" and the dominant work norms.

\section{References}

AKERLOF, G. (1982): Labor Contracts as Partial Gift Exchange, Quarterly Journal of Economics, 92, 543-569.

ASHENFELTER, O., AND D. CARD (1999): Handbook of Labor Economics, Amsterdam: Elsevier.

ASHENFELTER, O., AND R. LAYARD (1986): Handbook of Labor Economics, Amsterdam: Elsevier.

BELLEMARE, C., AND B. SHEARER (2011): On the Relevance and Composition of Gifts within the Firm: Evidence from Field Experiments, International Economic Review, $52,855-882$.

BENABOU, R., AND J. TIROLE (2003): Intrinsic and Extrinsic Motivation, Review of Economic Studies, 70, 489-520.

BOWLES, S. (1985): The Production Process in a Competitive Economy: Walrasian, Neo-Hobbesian, and Marxian Models, American Economic Review, 75, 16-36.

CAMERER, C., L. BABCOCK, G. LOEWENSTEIN, AND R. THALER (1997): Labor Supply of New York City Cabdrivers: One Day at a Time, Quarterly Journal of Economics, 112, 407-441.

CARPENTER, J., AND E. GONG (2016): Motivating Agents: How Much Does the Mission Matter?, Journal of Labor Economics, 34, 211-236.

COHN, A., E. FEHR, AND L. GOETTE (2014): Fair Wages and Effort Provision: Combining Evidence from a Choice Experiment and a Field Experiment, Management Science, In press.

CRAWFORD, V., AND J. MING (2011): New York City Cab Drivers' Labor Supply Revisited: Reference-Dependent Preferences with Rational-Expectations Targets for Hours and Income, American Economic Review, 101, 1912-1932.

DECI, E., AND R. RYAN (1985): Intrinsic Motivation and Self-Determination in Human Behavior. New York: Plenum. 
DICKINSON, D. (1999): An Experimental Examination of Labor Supply and Work Intensities, Journal of Labor Economics, 17, 638-670.

DOHMEN, T., A. FALK, D. HUFFMAN, AND U. SUNDE (2008): Representative Trust and Reciprocity: Prevalence and Determinants, Economic Inquiry, 46, 84-90.

FARBER, H. (2014): Why You Can't Find a Taxi in the Rain and Other Labor Supply Lessons from Cab Drivers, Quarterly Journal of Economics, forthcoming.

FEHR, E., AND L. GOETTE (2007): Do Workers Work More When Wages Are High? Evidence from a Randomized Field Experiment American Economic Review, 97, 298-317.

FISMAN, R., N. HARMON, E. KAMENICA, AND I. MUNK (2012): Labor Supply of Politicians.

GNEEZY, U., AND J. LIST (2006): Putting Behavioral Economics to Work: Testing for Gift Exchange in Labor Markets Using Field Experiments, Econometrica, 74, 1365-1384.

GNEEZY, U., AND A. RUSTICHINI (2000): Pay Enough or Don't Pay at All, Quarterly Journal of Economics, 115, 791-810.

HAMERMESH, D., AND J. WOLFE (1990): Compensating Wage Differentials and the Duration of Wage Loss, Journal of Labor Economics, 8, 175-197.

HEKMAN, J. (1993): What Has Been Learned About Labor Supply in the Past Twenty Years?, American Economic Review, 83, 116-121.

HEYMAN, J., AND D. ARIELY (2004): Effort for Payment: A Tale of Two Markets, Psychological Science, 15, 787-793.

HUET-VAUGHN, E. (2015): Do Social Comparisons Motivate Workers? A Field Experiment on Relative Earnings and Labor Supply.

JOHN, O., L. NAUMANN, AND C. SOTO (2008): Paradigm Shift to the Intergrated Big Five Trait Taxonomy, in Handbook of Personality: Theory and Research, ed. by O. John, R. Robins, and L. Pervin. New York: The Guilford Press, 114-158.

KEANE, M. (2011): Labor Supply and Taxes: A Survey, Journal of Economic Literature, 49, 961-1075.

KUBE, S., M. A. MARECHAL, AND C. PUPPE (2012): The Currency of Reciprocity: Gift Exchange in the Workplace, American Economic Review, 102, 1644-1662.

LEDFORD, G. (2014): The Changing Landscape of Employee Rewards: Observations and Prescriptions, Organizational Dynamics, 43, 168-179.

MCAUley, E., T. DUNCAN, AND V. TAMMEN (1989): Psychometric Properties of the Intrinsic Motivation Inventory in a Competitive Sport Setting: A Confirmatory Factor Analysis, Research Quarterly for Exercise and Sport, 60, 48-58.

OETTINGER, G. (1999): An Empirical Analysis of the Daily Labor Supply of Stadium Vendors, Journal of Political Economy, 107, 360-392. 
RYAN, R. (1982): Control and Information in the Intrapersonal Sphere: An Extension of Cognitive Evaluation Theory, Journal of Personality and Social Psychology, 43, 450-461. SAUERMANN, J. (2015): Worker Reciprocity and the Returns to Training: Evidence from a Field Experiment.

SILlAMAA, M.-A. (1999): Taxpayer Behavior in Response to Taxation: Comment and New Experimental Evidence, Journal of Accounting and Public Policy, 18, 165-177.

SWENSON, C. (1988): Taxpayer Behavior in Response to Taxation, Journal of Accounting and Public Policy, 7, 1-28. 


\section{Appendix - instructions from the experiment}

Part 1

$\{$ Participants are greeted and told to sign in as they arrive. They are then directed to their individual workstations and told to sign onto their computers using their college login information. When all participants are seated and logged on, the experimenter then reads the following instructions.\}

Hello, thank you for coming to this session. There are two parts to today's session, the first of which is an online survey we are asking you all to complete. Please note that any and all responses you provide are strictly confidential and anonymous. We intend to use the data collected from our study for academic work as it relates to economic decision-making. To assure your responses are confidential, we ask you to not speak to each other until the entire study is completed.

Inside the manila envelope on your desk you will find a consent form that we need you to fill out. Please take a moment to read over the form, sign it, and then return it to the envelope.

Inside the manila envelope you will also find a smaller envelope containing $\$ 5$. This is your compensation for completing the survey. We have allotted 30 minutes to complete the survey, and have based the compensation on the prevailing student worker wage, which is $\$ 10$ per hour.

It is now time to begin the survey, please launch an internet browser we will write a link on the board for you to follow to the survey. Once there, you will be prompted to enter your participant number, which is written on the outside of your manila envelope, and begin the survey. It is very important that you enter your participant number correctly.

Please begin. When you are finished please remain seated in your place - we will give you further instructions for part 2 after 30 minutes have passed.

\{At the end of Part 1 participants are told to take a minute to get a drink, stretch, or use the bathroom while the room is readied for production. $\}$

Part 2

It is time to begin part 2. For those of you still working on the survey, you can stop where you are. Thank you all very much for your responses.

For the second half hour of our session, we would like you to help the Economics Department prepare a newsletter mailer that will be sent to alumni. The work is simple. You will fold the mailer in thirds so the return address is showing, \{folding is demonstrated $\}$ place a round sticker on the seam so it doesn't open in the mail and then hand address the mailer using a list of alumni that we have provided. Please do one mailer at a time and don't worry 
about the year of graduation.

$\{$ Wage $=\$ 0\}$ Ordinarily, the Department would have to hire student workers to do this task, but we'd like you to stay for another 30 minutes to work on the mailer as a volunteer. $\{$ Wage $=\$ 10\}$ Ordinarily, the Department would have to hire student workers to do this task, but we'd like you to stay for another 30 minutes to work on the mailer. Regardless of how many mailers you complete, you will be paid an additional $\$ 10$ at the end of the 30 minutes, from funds provided by the Economics Department. 


\begin{tabular}{|c|c|c|c|c|}
\hline \multicolumn{5}{|c|}{ Table A1: Full Output Regressions } \\
\hline & $(1)$ & $(2)$ & $(3)$ & $(4)$ \\
\hline \multirow[t]{2}{*}{ Wage } & -0.112 & -0.143 & -0.104 & $-0.143^{*}$ \\
\hline & $(0.107)$ & $(0.105)$ & $(0.139)$ & $(0.086)$ \\
\hline \multirow[t]{2}{*}{ Age } & & 0.284 & & 0.284 \\
\hline & & $(0.479)$ & & $(0.605)$ \\
\hline \multirow[t]{2}{*}{ Male (I) } & & $-5.177^{* * *}$ & & $-5.177^{* * *}$ \\
\hline & & $(1.720)$ & & $(1.359)$ \\
\hline \multirow[t]{2}{*}{ Caucasian (I) } & & 1.247 & & 1.247 \\
\hline & & $(1.420)$ & & $(1.385)$ \\
\hline \multirow[t]{2}{*}{ High GPA (I) } & & 1.885 & & 1.885 \\
\hline & & $(1.511)$ & & $(1.595)$ \\
\hline \multirow[t]{2}{*}{ Economic Major (I) } & & $2.625^{*}$ & & 2.625 \\
\hline & & $(1.482)$ & & $(1.745)$ \\
\hline \multirow[t]{2}{*}{ Extroversion (FS) } & & -0.105 & & -0.105 \\
\hline & & $(0.883)$ & & $(0.687)$ \\
\hline \multirow[t]{2}{*}{ Agreeableness (FS) } & & $-1.665^{*}$ & & $-1.665^{* *}$ \\
\hline & & $(0.871)$ & & $(0.764)$ \\
\hline \multirow[t]{2}{*}{ Conscientiousness (FS) } & & -0.611 & & -0.611 \\
\hline & & $(1.012)$ & & $(0.801)$ \\
\hline \multirow[t]{2}{*}{ Neuroticism (FS) } & & -0.359 & & -0.359 \\
\hline & & $(0.662)$ & & $(0.699)$ \\
\hline \multirow[t]{2}{*}{ Openness (FS) } & & 0.332 & & 0.332 \\
\hline & & $(0.855)$ & & $(0.783)$ \\
\hline Errors clustered on session & Yes & Yes & No & No \\
\hline Session random effects & No & No & Yes & Yes \\
\hline Observations & 175 & 175 & 175 & 175 \\
\hline
\end{tabular}

Notes: Dependent variable is individual output; marginal effects and robust standard errors reported; ${ }^{*} \mathrm{p}<0.10 * *{ }^{*} \mathrm{p} 0.05,{ }^{* * *} \mathrm{p} \mathrm{i} 0.01$. 


\begin{tabular}{|c|c|c|c|c|}
\hline Table A2: Output Regre & Ions with & $\frac{\text { eciproca }}{(2)}$ & $\frac{\text { nd Intrin }}{(3)}$ & $\frac{\text { Workers }}{(4)}$ \\
\hline \multirow[t]{2}{*}{ Wage } & -0.202 & -0.216 & -0.182 & $-0.216^{*}$ \\
\hline & $(0.117)$ & $(0.133)$ & $(0.173)$ & $(0.120)$ \\
\hline \multirow[t]{2}{*}{ Reciprocal Worker (I) } & $-4.001^{* *}$ & $-3.583^{* *}$ & $-3.846^{* * *}$ & $-3.583^{* *}$ \\
\hline & $(1.499)$ & $(1.560)$ & $(1.489)$ & $(1.649)$ \\
\hline \multirow[t]{2}{*}{ Wage $\times$ Reciprocal Worker } & $0.662^{* * *}$ & $0.601^{* * *}$ & $0.664^{* * *}$ & $0.601^{* * *}$ \\
\hline & $(0.120)$ & $(0.129)$ & $(0.159)$ & $(0.166)$ \\
\hline \multirow[t]{2}{*}{ Intrinsic Worker (I) } & $6.297^{* * *}$ & $5.720 * *$ & $6.437^{* * *}$ & $5.720^{* * *}$ \\
\hline & $(1.993)$ & $(2.365)$ & $(1.554)$ & $(1.687)$ \\
\hline \multirow[t]{2}{*}{ Wage $\times$ Intrinsic Worker } & $-0.359^{* * *}$ & $-0.339^{*}$ & $-0.375^{* *}$ & $-0.339^{* *}$ \\
\hline & $(0.142)$ & $(0.189)$ & $(0.164)$ & $(0.173)$ \\
\hline \multirow[t]{2}{*}{ Age } & & 0.143 & & 0.143 \\
\hline & & $(0.447)$ & & $(0.574)$ \\
\hline \multirow[t]{2}{*}{ Male (I) } & & $-4.085^{* * *}$ & & $-4.085^{* * *}$ \\
\hline & & $(1.662)$ & & $(1.300)$ \\
\hline \multirow[t]{2}{*}{ Caucasian (I) } & & 1.405 & & 1.405 \\
\hline & & $(1.378)$ & & $(1.321)$ \\
\hline \multirow[t]{2}{*}{ High GPA (I) } & & 0.592 & & 0.592 \\
\hline & & $(1.297)$ & & $(1.523)$ \\
\hline \multirow[t]{2}{*}{ Economic Major (I) } & & $2.391^{*}$ & & 2.391 \\
\hline & & $(1.201)$ & & $(1.641)$ \\
\hline \multirow[t]{2}{*}{ Extroversion (FS) } & & 0.019 & & 0.019 \\
\hline & & $(0.931)$ & & $(0.648)$ \\
\hline \multirow[t]{2}{*}{ Agreeableness (FS) } & & $-1.589^{* *}$ & & $-1.589^{* *}$ \\
\hline & & $(0.637)$ & & $(0.724)$ \\
\hline \multirow[t]{2}{*}{ Conscientiousness (FS) } & & -0.201 & & -0.201 \\
\hline & & $(1.038)$ & & $(0.724)$ \\
\hline \multirow[t]{2}{*}{ Neuroticism (FS) } & & -0.168 & & -0.168 \\
\hline & & $(0.662)$ & & $(0.661)$ \\
\hline \multirow[t]{2}{*}{ Openness (FS) } & & 0.642 & & 0.642 \\
\hline & & $(0.666)$ & & $(0.747)$ \\
\hline Errors clustered on session & Yes & Yes & No & No \\
\hline Session random effects & No & No & Yes & Yes \\
\hline Observations & 175 & 175 & 175 & 175 \\
\hline
\end{tabular}

Notes: Dependent variable is individual output; marginal effects and robust standard errors reported; ${ }^{*} \mathrm{p}<0.10,{ }^{* *} \mathrm{p}<0.05,{ }^{* * *} \mathrm{p}<0.01$. 